\title{
MOTIVATIVE EFFECTS OF MEDIA ON STUDENT EDUCATION
}

\author{
Dilorom Hujakulova
}

Ph.D., Associate Professor Of The Tashkent Institute Of Textile And Light Industry, Uzbekistan

\section{ABSTRACT}

The article is devoted to the motivational influence of information technologies on the teaching of schoolchildren. The article also highlights the issues of youth education, types of education and its pedagogical measures, education of youth in the context of globalization, innovation and youth, the impact of modern information technologies on the consciousness of youth and its motivating factors.

KEYWORDS:- Youth, upbringing, education, globalization, society, teacher, information, technology, virtual system, informatics, idea, popular culture, behaviour.

\section{INTRODUCTION}

The school has always served as a bridge between yesterday, today and the future in any system and society. For this reason, in the modern world, society's requirements for school are growing day by day, and the task of solving these requirements in practice depends on the teacher.

As the modern school adapts its activities to the requirements of a rapidly and rapidly evolving society, in accordance with the new requirements, in the long run, it is necessary to provide students not only with theoretical knowledge, skills and abilities, but also personal development. goal-oriented individual qualities, in which the formation of basic competencies necessary for future personal, professional and social activities. In a modern school today, a modern teacher cannot be a social psychologist. Therefore, it is necessary to be able to establish relationships between students, to know the use of socio-psychological mechanisms in the children's community, to understand the motivation of students.

As the sages of the East say, "The greatest wealth is intelligence and knowledge, the greatest heritage is good upbringing, and the greatest poverty is ignorance!"

That is why it is necessary for all of us to acquire modern knowledge, to have true enlightenment and high culture.

Today's society needs young people who can clearly see the content of their work and solve any problem independently.

"Today's youth is the largest generation in human history, numbering 2 billion," he said. The future of our planet depends on how our children grow up to be human beings. Our main task is to create the necessary conditions for young people to show their potential, to prevent the spread of the idea of violence - the "virus". About $64 \%$ of the population is young people under 30 years old. This, on the one hand, imposes a great responsibility on our state, and on the other 
hand, provides great opportunities as a result of an appropriate youth policy.

Today, more than half of the labor force in Uzbekistan is young. Young people are an active part of society at all times and need constant guidance, support and encouragement. So what is the impact of these media on student education? There are two possible answers to the question, negative or positive. On the plus side, newspapers, magazines, and television broadcasts are available, and awareness-raising classes are held.

On the downside, the interviews revealed ageinappropriate series, interest in militant films, and more. In fact, as a person grows, he usually has a predominant tendency towards some kind of activity, and this situation can determine his way of life and destiny. Psychologists try to prove this tendency inherent in human activity on the basis of experimental conclusions. According to BI Dodonov, a person can achieve "proportionality" not through the development of all his qualities, but through the superior development of his abilities, which give him the essence and meaning, which is the basis of his whole life and activity. In practical activity, the expression and emergence of a person's social qualities only as a person is his cultural criterion.

True identity can be achieved, not by striving for originality, but, above all, by hard work.

As a result of "unfiltered" reception of messages in the global information system, the minds of young people are being poisoned.

For example, young people who come to the site to get the necessary information, see a sensational announcement, such as "So-and-so celebrity has crashed," and involuntarily open it and read the rest of the deceptive news. In this way, the young people of the cave fall into the trap of the aliens. A teenager exposed to such a disgusting "culture" will grow up to be indifferent, easy-going, indifferent to the development of the country and the peace of the people.

The intensity of the information age, the reforms in information security, the formation of the ability to understand the essence of the information flow coming to us in the mirror of reason, thinking, and the ability to sort information, the ideological requires serious attention to the qualities of struggle. The following characteristics should be developed in young students in order to prevent the negative impact of the information provided on the motivation of students.

First of all, it is necessary to cultivate a culture of being able to select, sort, analyze, use and comprehend the information provided, to develop the skills of critical evaluation.

The ability to choose information, to understand the content of the ideas put forward in the information, to eliminate the negative, harmful aspects of the ideology, means that the culture of perception is sufficiently formed. One of the important issues is the formation of a culture of student use of the media, increasing the pedagogical role of modern media in the educational process, which is the main focus of the current processes of globalization and the spiritual threats they face, especially in the system of comprehensive reforms in education. Educator N.T. Omonov says that the fruits of the information revolution can be seen in the fact that there is a huge amount of information processing and access to books stored in the libraries of any country. Radio, television, and the Internet provide the latest scientific news to the world in a short period of time, allowing everyone to benefit from the achievements of science, culture, literature, and the arts. No matter how much the benefits of new information technologies are recognized, it must not be overlooked that the human intellect, the 
will, and even the spiritual world are dependent on the ever-evolving technical means of information.The media has a great potential to influence people's minds and emotions, their way of thinking and their behavior.

Today's development of the media has led to a dramatic increase in the scale and scope of ideological influence.The peculiarity of ideological influence and pressure, which is carried out through the media and does not require large sums of money, is that it is carried out without the knowledge of the reader, listener or viewer and does not cause direct casualties. Information is highly effective without destroying the enemy and without incurring significant costs.

The main focus is on influencing people's minds and worldviews, changing existing values, reducing or eliminating their regulatory role, with a serious study of the aspirations, mentality, and existing problems of the population of ideologically influenced countries. focused.

Periodicals skillfully use gradual, fragmentary methods of radio and television transmission to influence this.

The pace of modern information today is so intense and fast that it can no longer be ignored.

According to researchers M. Pardaeva, 0. Musurmonkulova, A. Kushmanov, in solving such an important problem, it is necessary to pay attention to the following aspects.

First, to ensure that teachers make extensive use and accurate delivery of modern media materials in the teaching process;

Second, to develop students' attitudes and culture towards modern media as a source of knowledge;

Third, in every family, parents should be more active in educating their children to pay attention to the educational content of the information disseminated through modern media, and to cultivate a critical thinking attitude towards the information provided, and so on.

\section{Conclusion}

In short, if the achievement of information literacy in the organization of information literacy and information security is formed in these computer science classes, information security will be strengthened by law.

\section{REFERENCES}

1. R.S. Kasimov and others. "Scientific and popular guide to the study of the Address of the President of the Republic of Uzbekistan Shavkat Mirziyoyev to the Oliy Majlis and its dissemination among the general public" Tashkent "Manaviyat" 2018. Pages 119, 243

2. Dodonov B. I. Emotions as tsennost.- M., 2008. - $145 \mathrm{p}$.

3. Omonov NT Pedagogical technologies and pedagogical skills - T .: "Economics and Finance". 2009. - 126 p.

4. M.Pardaeva, O.Musurmonkulova, A.Kushmanov, "The environment in the education of teachers: problems and solutions." Republican Education Center of the Ministry of Public Education of the Republic of Uzbekistan; Toshkent-2015.$152 \mathrm{p}$. 